\title{
A legelterjedtebb hazai trágyázási szaktanácsadási rendszerek tesztelése szabadföldi kísérletekben
}

\section{Bevezetés}

A hazai agrokémiai iskolák által beállított és publikált tartamkísérletek adatbázisán (ÁRENDÁs \& CSATHÓ, 1994, 2002; BERZSENYI, 1993; CSATHÓ, 1997, 2001a,b, 2002, 2003a,b,c,d,e, 2004, 2005a,b; DEBRECZENI \& DEBRECZENINÉ, 1994; KÁDÁr, 1992; KADliCSKÓ et al., 1988; KRISZTiÁn \& Holló, 1991; LÁSZTITY, 1989; NAGY, 1995; NÉMETH, 2006 stb.) kapott összefüggésekre alapozva az 1990-es évek közepén egy új szemléletü, költség- és környezetkímélő trágyázási szaktanácsadási rendszer fejlesztése kezdődött meg (CSATHÓ et al., 1998a,b; 2003, 2004a, 2005d). A számítógépes szaktanácsadási rendszer segítséget kíván nyújtani a növénytermesztô szakembereknek a rendelkezésükre álló tápanyagforrások ésszerủ és gazdaságos felhasználásához. A 48 legfontosabb szántóföldi növény trágyázási szaktanácsadási rendszerét az MTA Talajtani és Agrokémiai Kutatóintézet (Budapest) és az MTA Mezőgazdasági Kutatóintézet (Martonvásár) szakemberei dolgozták ki (CsATHÓ et al., 1998a,b; 2003; NÉMETH et al., 2001). Elkészült a 38 legfontosabb szántóföldi zöldségnövény (TERBE et al., 2004, 2005; CSATHÓ et al., 2004b, 2005c;), a gyümölcs (SzÜCS, 2006) és szőlő (SzÖKE, 2006) fenntartó trágyázási irányelvének szoftvere is. Az új szaktanácsadási rendszer megalkotói a korábbi szaktanácsadási rendszerek értékeit igyekeztek beépíteni az új rendszerbe: ID. VÁRALLYAY (1950) az adott elemre igényes, ill. kevésbé igényes növénycsoportra külön talaj PK-ellátottsági határértékeket; a MÉM NAK (1979) intenzív rendszer mérlegszemléletủ megközelítését; a Sarkadi-féle AL-P korrekciós modellt (SARKADI et al., 1987), az MTA TAKI-KSzE integrált rendszer megközelítését, amely a talaj NPKellátottsági határértékeket egyes talajtulajdonságok (fizikai féleség, $\mathrm{pH}, \mathrm{CaCO}_{3}$ tartalom) függvényében alkotja meg (VÁRALLYAY et al., 1992) stb.

Ha a nemesítők egy-egy új, ígéretes fajtajelöltet állítanak elő, ezeket a jelölteket - nagyon indokoltan - több éves tesztkísérleteknek vetik alá. A gazdálkodók csak azokkal az új fajtákkal, hibridekkel találkozhatnak, amelyek az igen erős, jó képességủ standard fajták, hibridek felett is plusz teljesítményt nyújtottak. Ezáltal jelentösen csökken a gazdálkodó kockázata, amelyet egy nem megfelelően teljesítő új fajta, hibrid jelentene.

Ezzel szemben egy-egy új trágyázási szaktanácsadási rendszert - avagy egy 25-30 éves régit, amelyet egészen más gazdasági környezetre ill. a környezetvédelmi szabályrendszer előtti időkre dolgoztak ki - ma Magyarországon mindenféle korlátozás nélkül lehet használni az Európai Unió égisze alatt meghirdetett Nemzeti Vidékfejlesztési Terv Agrár-környezetgazdálkodási (NVT AKG) Programjában. A Programban sajnálatosan semmiféle, a költség- illetve környezetkímélő szempontok szigorú teljesítésére irányuló feltételrendszert nem fogalmaztak meg a programban résztvevő/engedélyezett szakta- 
nácsadási rendszerekkel szemben. Erre pedig - éppen a gazdálkodók védelmében sürgető szükség lenne. A téma fontosságát jelzi, hogy egy vezető havilap a közelmúltban tápanyag-gazdálkodási fórumot szervezett, amelynek anyaga nyomtatásban is megjelent (Gyakorlati Agrofórum, 2006).

A Nemzetközi Foszfor Intézet (IMPHOS) egy hároméves program keretében vállalta a magyarországi trágyázási szaktanácsadási rendszereknek jellegzetes hazai talajokon, legfontosabb növényeinkkel történő tesztelésének finanszírozását. Az új fajtákhoz hasonlóan a trágyázási szaktanácsadási rendszereket is szükséges szabadföldi tesztkísérleteknek alávetni, és csak a megfelelöen teljesítőket engedni a köztermesztésbe.

A három jellegzetes hazai talajon (barna erdőtalaj, csernozjom, réti talaj), három növénnyel (őszi búza, kukorica, tavaszi árpa) beállított ún. IMPHOS kísérletek eredményeiröl ezideig csupán a gyakorlati gazdák részére számoltunk be népszerüsítő cikkekben (CSATHÓ et al., 2005a,b, 2006a,b,c,d,e).

A világ, és hazánk legfontosabb trágyázási szaktanácsadási rendszereiről, azok fejlődéséröl és müködési alapelveiröl BALLÁNÉ (1991a,b, 1992a,b, 1993, 1994) adott átfogó értékelést.

\section{Az új, költség-és környezetkímélő trágyázási szaktanácsadási rendszer ismertetése}

Az új, környezet- és költségkímélő trágyázási szaktanácsadási rendszer négy mütrágyázási szinten ad szaktanácsot: 1. minimum; 2. környezetkímélö; 3. mérlegszemléletü és 4. maximum növénytáplálási szint. A minimum növénytáplálási szinten PKtrágyázást a jó és annál magasabb ellátottságokon, a környezetkímélő növénytáplálási szinten az igen jó és annál magasabb PK-ellátottságtól nem javasol a program. Amenynyiben ezt a trágyázási gyakorlatot folytatjuk, a közepes PK-ellátottságot fogjuk elérni, ill. fenntartani. A mérlegszemléletü és a maximum növénytáplálási szinteken az ellátottsági kategóriától függő szorzószámok nagyobbak, és még az igen jó PK-ellátottságon is javasol csökkentett mennyiségű PK-trágyázást. E két növénytáplálási szinten a jó PKellátottság elérése, ill. fenntartása a cél. A túlzott PK-ellátottsági szinten viszont már egyik változat sem javasol PK-trágyázást. Ugyanakkor, még a legmagasabb, a maximum növénytáplálási szinten is jóval alacsonyabbak a javasolt adagok, mint az intenzív (MÉM NAK, 1979) szaktanácsadási rendszer ajánlásai, különösen a jó, igen jó, és túlzott talaj PK-ellátottsági szinteken.

$\mathrm{Az}$ 1. és 2. változatok (minimum, ill. környezetkímélő mütrágyázási ajánlások) célja a legnagyobb jövedelmet biztosító termésszintek (a maximális termésszint mintegy 95\%-a) biztosítása a közepes talaj PK-ellátottság elérése, ill. fenntartása útján. A 3. és 4. változatok (mérlegszemléletü, ill. maximum mütrágyázási ajánlások) nagyobb adagokkal, de továbbra sem intenzív mütrágyázással a maximális terméseket célozza meg. Ez a gyakorlat javasolható a vetőmagtermesztésben, és pl. a minőségi búzatermesztésben is. Feltétel ugyanakkor, hogy az érintett terület ne tartozzon a környezeti szempontból különösen érzékeny területek közé. A rendszer mütrágyaigényt csökkentő tényezőként figyelembe veszi a korábbi szervestrágya-kijuttatást, a pillangós előveteményt, az elővetemény betakarításának időpontját, az elővetemény területen maradó melléktermésének tápanyagtartalmát stb. 
Az egy hektárra javasolt $\mathrm{N}-, \mathrm{P}_{2} \mathrm{O}_{5^{-}}$, és $\mathrm{K}_{2} \mathrm{O}$-mütrágya hatóanyag-mennyiségeket $(x)$ a program az alábbi képlet szerint számolja:

$$
x=\left(T \cdot F_{t} \cdot S z\right) \pm K
$$

ahol: $\mathrm{T}=$ tervezett termésszint, $\mathrm{t} / \mathrm{ha} ; \mathrm{F}_{\mathrm{t}}=$ tervezett termésszinthez tartozó fajlagos táp-elemigény; $\mathrm{sz}=\mathrm{a}$ talaj tápelem-ellátottsági kategóriától függő szorzószám; K= korrekciós faktor.

\section{A környezetkímélő, valamint az intenzív trágyázási szaktanács- adási rendszerek alapelveinek összehasonlítása}

Figyelembe véve az utóbbi 15 év hazai tápanyag-gazdálkodásának kihívásait, a műtrágyaár-támogatások megszüntetését, a megszigorodott gazdasági környezetet, a korábbi szaktanácsadási módszerek értékeit megőrizve, 48 legfontosabb szántóföldi, ill. 38 szántóföldi zöldségnövényünk új szemléletü, költségtakarékos, környezetkímélő makroés mikroelem-trágyázási rendszere került kidolgozásra. A korábbi intenzív (MÉM NAK, 1979, „,kék füzet”) rendszer történelmi küldetést töltött be, amikor talajaink PKellátottságának gyors javítását, és az élelmiszerellátás biztonságát, mint fontos stratégiai feladatot is biztosította. Mezőgazdaságunk jelentős - de rohamosan csökkenő - részben ma is az akkor felhalmozott PK tápelem tőkéből él. Az intenzív, valamint az új, költségés környezetkímélő trágyázási szaktanácsadási rendszer filozófiájának összehasonlítását az 1. táblázatban tanulmányozhatjuk.

I. Az intenzív mütrágyázás időszakában készített hazai trágyázási szaktanácsadási rendszerek célul tűzték ki talajaink PK-ellátottságának gyors javítását, a stabilan nagy

\section{1. táblázat}

Az intenzív tápanyagellátást biztosító, valamint a környezetkímélő trágyázási szaktanácsadási rendszerek összehasonlítása (CsATHÓ et al., 1998a,b, 2004a,b)

\begin{tabular}{|l|l|}
\hline \multicolumn{1}{|c|}{$\begin{array}{c}\text { Intenzív tápanyagellátás rendszere } \\
\text { (MÉM NAK, 1979) }\end{array}$} & $\begin{array}{c}\text { Környezetkímélő trágyázási rendszer } \\
\text { (MTA TAKI-MTA MGKI) }\end{array}$ \\
\hline Maximális termésszintre való törekvés & Gazdaságos termésszintre való törekvés \\
\hline A „talaj trágyázása” a cél & A „növény trágyázása” a cél \\
\hline $\begin{array}{c}\text { Jó-igen jó talaj PK-ellátottság elérése, } \\
\text { majd fenntartása }\end{array}$ & $\begin{array}{c}\text { Közepes-jó talaj PK-ellátottság elérése, } \\
\text { majd fenntartása }\end{array}$ \\
\hline Gyors talaj PK-feltöltés & Lassú talaj PK-feltöltés \\
\hline $\begin{array}{c}\text { Minden évben PK-trágyázás } \\
\text { A vetésforgó PK-trágyázása } \\
\text { (periodikus PK-trágyázás) }\end{array}$ \\
\hline $\begin{array}{c}\text { PK-trágyázás minden talaj PK-ellátottsági } \\
\text { szinten }\end{array}$ & $\begin{array}{c}\text { PK-trágyázás csak jó-közepes és annál gyen- } \\
\text { gébb talaj PK-ellátottsági szinten }\end{array}$ \\
\hline $\begin{array}{c}\text { Nagyobb talaj tápelem-ellátottsági } \\
\text { határértékek }\end{array}$ & $\begin{array}{c}\text { Kisebb talaj tápelem-ellátottsági } \\
\text { határértékek }\end{array}$ \\
\hline $\begin{array}{c}\text { Egységes talaj tápelem-ellátottsági } \\
\text { határértékek }\end{array}$ & $\begin{array}{c}\text { Növénycsoporttól függö talaj tápelem- } \\
\text { ellátottsági határértékek }\end{array}$ \\
\hline Nagyobb fajlagos tápelemtartalmak & Kisebb fajlagos tápelemtartalmak \\
\hline $\begin{array}{c}\text { A tervezett termésszinttöl független fajlagos } \\
\text { tápelemtartalmak }\end{array}$ & $\begin{array}{c}\text { A tervezett termésszinttöl függö } \\
\text { fajlagos tápelemtartalmak }\end{array}$ \\
\hline
\end{tabular}


termések elérését. Ennek eredményeképpen az 1950-es évekkel összehasonlítva a '70es, '80-as évekre fontosabb termesztett növényeink termésátlaga 2-3-szorosára emelkedett. A maximális termések elérésére irányuló törekvések a későbbiekben is megmaradtak (10 tonnások klubja, gabonaprogram stb.). A rendszer bizonyos fokig magában hordozta a környezetszennyezés lehetőségét (nitrát N-lemosódás) és a tápelem antagonizmusok kialakulását (P-Zn) is, a gazdaságossági kérdésekről nem is szólva (Kádár, 1988; Németh et al., 1987-1988; Csathó et al., 1989; Ángyán \& Menyhért, 1997, 2004). Ebben az időszakban a mütrágya-felhasználás jelentős állami dotációt élvezett. A nitrogén esetében a biztonságosan magas termés elérése céljából enyhe túltrágyázásra törekedtek, míg a foszfor és a kálium vonatkozásában a jó-igen jó talaj tápelem-ellátottság elérését, illetve fenntartását célozták meg. Így végül is nem annyira a növény, mint a talaj trágyázása volt a cél. Magyarország mütrágyázási gyakorlatára ez volt jellemző a '70-es, '80-as években, és ennek megfelelöen - szakmailag legnagyobb részt indokoltan - jelentősen javult talajaink PK-ellátottsága ezen időszak végére. A fejlett, nagy népsürüségű nyugat-európai országok növénytáplálási gyakorlata ma is többé-kevésbé erre az alapelvre épül.

Itt kell megjegyeznünk, hogy a '70-es, '80-as években egyes területeken a bizonyos fokú túltrágyázási gyakorlatot elősegíthették a szakmai elveket nélkülöző politikai elvárások is, az üzemek - a szaktanácsadási rendszer ajánlásait figyelmen kívül hagyva - a jó-igen jó ellátottságú területeken ugyanannyi mütrágyát juttattak ki, mint a gyenge ellátottságú területeken (BUZÁSNÉ et al., 1988).

II. Az 1980-as évek végének-’90-es évek elejének politikai-gazdasági változásai nyilvánvalóvá tették, hogy az ország gazdasági helyzete, teherbíró képessége nem teszi lehetővé a korábbi mütrágyázási gyakorlat folytatását.

Az új szemléletü, környezetkímélő trágyázási rendszer kisebb mütrágyaadagok kijuttatásával biztosítja a gazdaságos termésszintek elérését. A jelenlegi körülmények között a „talaj trágyázása” helyett a növény adott évi tápelemigényének harmonikus biztosítását kell célul kitüzünk. A N-igény minél pontosabb kielégítése a cél. Foszfor és kálium vonatkozásában a jó-igen jó ellátottság helyett legtöbbször a közepes ellátottság elérésére, ill. fenntartására szükséges törekedni. A maximális termések helyett a legnagyobb nettó jövedelmeket biztosító termésszintet (általában a maximális termések 90 $95 \%$-át) célszerü elérni. A három makrotápelem $(\mathrm{N}, \mathrm{P}$ és $\mathrm{K})$ együttes kijuttatása minden növény alá és minden talaj tápelem-ellátottsági szint mellett többé már nem természetes. A vetésforgón belül pl. közepes K-ellátottság mellett a K-igényes kapások számára kijuttatott K utóhatása elegendő lesz a következő évben ott termesztett kalászos mérsékeltebb K-szükségletének biztosítására. Szintén közepes P-ellátottság mellett a nagyobb P-igényü kalászosok számára kijuttatott $\mathrm{P}$ utóhatása viszont a kisebb P-szükségletü következő évi kapás részére fog elegendő foszfort biztosítani.

Sajnos, sok gazdaság, egyéni termelő még a közepes PK-ellátottsághoz szükséges tápanyagmennyiségeket sem képes biztosítani, melynek várható következménye a termesztett növények közepes, vagy súlyos alultápláltsága, az alacsony termésszintek, a mennyiség és a minőség jelentős ingadozása. Ebben az esetben már csak extenzív növénytáplálásról beszélhetünk. 


\section{A környezetkímélő, valamint az intenzív tápanyagellátást elősegítő, ill. egyéb szaktanácsadási rendszerek ajánlásainak testelése szabadföldi kísérletben}

Az IMPHOS finanszírozásával 2003 őszén három éves program keretében 3 ismétléses, véletlen blokk elrendezésű szabadföldi kisparcellás kísérletekben (bruttó parcellaméret: 74-80 $\mathrm{m}^{2}$ ) kezdtük meg tesztelni környezetkímélő trágyázási szaktanácsadási rendszerünk, valamint az intenzív tápanyagellátást elősegítő, ill. egyéb szaktanácsadási rendszerek ajánlásait. Az első évben mindhárom kísérletben őszi búza (nitrogénre és foszforra igényes, káliumra kevésbé igényes) növény szerepelt. 2005-ben nitrogénre és káliumra igényes, foszforra kevésbé igényes kukoricát vetettünk, 2006-ban tavaszi árpa (nitrogénre és foszforra igényes, káliumra kevésbé igényes) volt a kísérletekben.

\section{Az IMPHOS öszi búza kisérletek, 2004}

2003/2004-ben az őszi búzára kedvezően alakult az időjárás, amely a nagy termésátlagokban is megnyilvánult. Az első évben őszi búza alá javasolt mütrágyaadagokról, a kapott szemtermés-mennyiségekről a 2. táblázat tájékoztat.

Balatonszentgyörgy. - Ramann-féle barna erdőtalaj. Talajtulajdonságok: fizikai féleség: homokos vályog; $\mathrm{pH}(\mathrm{KCl}): 6,45 ; \mathrm{CaCO}_{3}$-tartalom: 0 ; szervesanyag-tartalom: 1,62\%; N-ellátottság: gyenge. AL- $\mathrm{P}_{2} \mathrm{O}_{5}: 107 \mathrm{mg} / \mathrm{kg}$ (közepes P-ellátottság); $\mathrm{AL}-\mathrm{K}_{2} \mathrm{O}$ : $156 \mathrm{mg} / \mathrm{kg}$ (jó K-ellátottság). Elővetemény: 2,2 t/ha repce, a szalmát leszántották. Tervezett termésszint: 5,0 t/ha őszi búza.

A kísérlet első 6 kezelése egy klasszikus hiánykísérlet. Ezzel célunk a rendszerek által megállapított NPK-ellátottsági kategóriák helyességének az ellenőrzése volt. A 7. és 8. kezelések 3 évi foszfor-elöretrágyázást jelentenek, tehát a következő két évben ezek a parcellák P-trágyázásban nem részesednek. Az 5. és 6. kezelésekben évente, az őszi alapmüvelés előtt adjuk ki a foszfort az adott növény alá.

A kísérletben 2,4 t/ha N-hatást, 0,6 t/ha P-hatást és 0,0 t/ha K-hatást mértünk. Az NPK-hatások jól követték az általunk megadott NPK-ellátottságokat (2. táblázat).

Mindenképpen figyelemreméltó, hogy az MTA TAKI-MTA MGKI-2 (környezetkímélő szint) a MÉM NAK intenzív ajánlás 56\%-ának megfelelő összes NPK kijuttatásával a MÉM NAK rendszerével azonos termésátlagot eredményezett, teljesítve a rendszer megalkotásakor megfogalmazott célt: a lehető legkisebb NPK-adagokat juttassuk ki úgy, hogy közben a termésbiztonságot, a potenciálisan nagy termésszinteket ne veszélyeztessük (2. táblázat).

Mezőkövesd. - Réti talaj. Talajtulajdonságok: fizikai féleség: agyagos vályog; pH( $\mathrm{KCl})$ : 4,49; $\mathrm{CaCO}_{3}$-tartalom: 0; szervesanyag-tartalom: 3,43\%; $\mathrm{N}$ ellátottság: jó. AL- $\mathrm{P}_{2} \mathrm{O}_{5}: 38 \mathrm{mg} / \mathrm{kg}$ (gyenge P-ellátottság); AL- $\mathrm{K}_{2} \mathrm{O}: 209 \mathrm{mg} / \mathrm{kg}$ (igen jó K-ellátottság). Elővetemény: 3,0 t/ha napraforgó, a szárat alászántották. A terület vetés előtt $2 \mathrm{t} / \mathrm{ha}$ meszet kapott. Tervezett termésszint: 5,5 t/ha öszi búza.

A kísérlet klasszikus hiánykísérlet részében $0,4 \mathrm{t} /$ ha $\mathrm{N}$-hatást, $0,8 \mathrm{t} / \mathrm{ha}$ P-hatást és 0,0 t/ha K-hatást kaptunk. Az NPK-hatások a balatonszentgyörgyi kísérletnél is jobban igazolták az új rendszer által megadott NPK-ellátottságok helyes voltát. A 2003/2004. évi időjárás az őszi búzára igen kedvezően alakult. Ezt igazolja a kísérlet átlagában kapott 10,6 t/ha-os termésszint is (2. táblázat). 


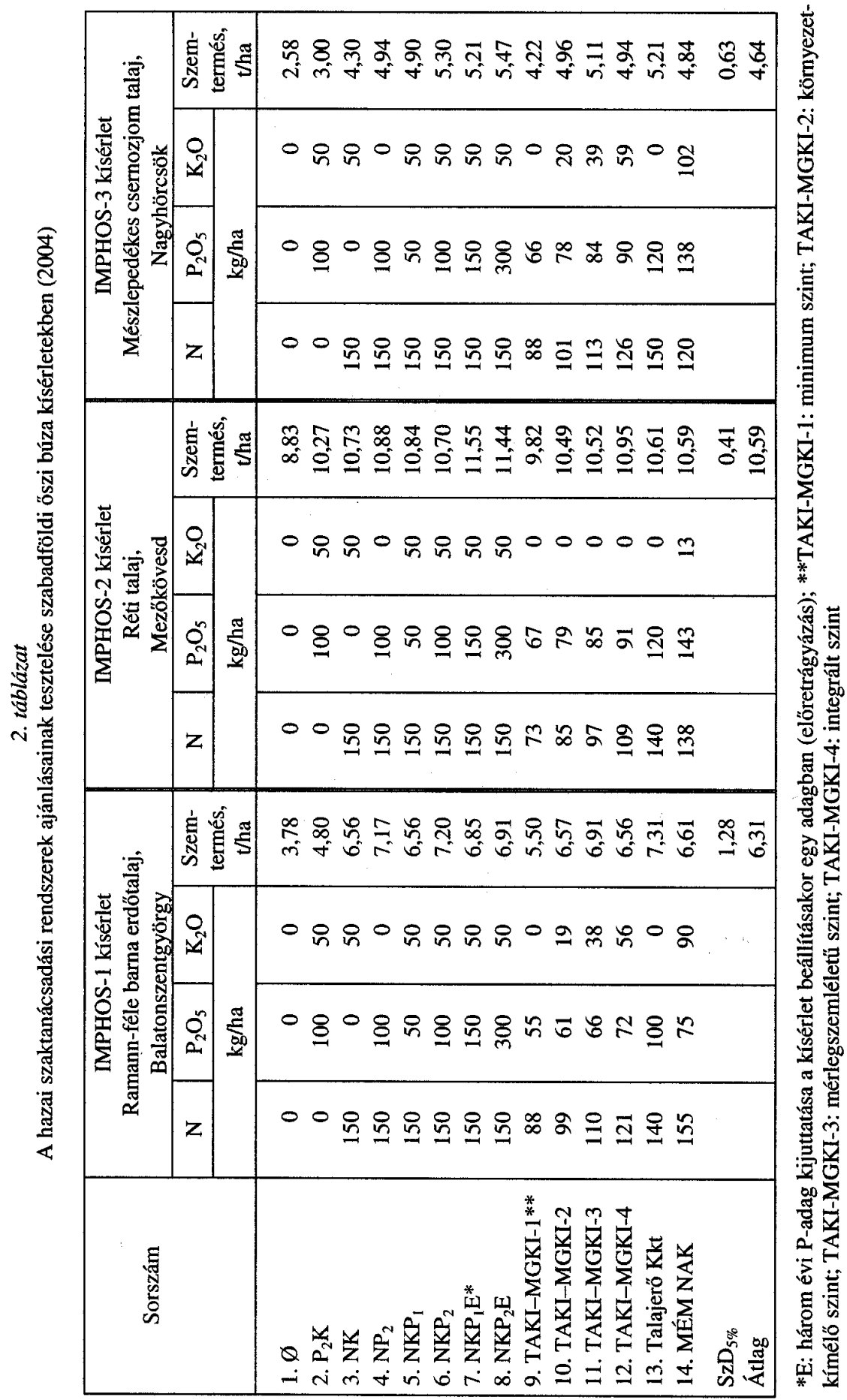


A balatonszentgyörgyi kísérlethez hasonlóan, az MTA TAKI-MTA MGKI-2 (környezetkímélő szint) a MÉM NAK intenzív ajánlás 56\%-ának megfelelő összes NPK ( $\mathrm{kg} / \mathrm{ha})$ kijuttatásával a MÉM NAK intenzív ajánlásával azonos termésátlagot produkált. E kísérletben is teljesült a rendszer megalkotásakor megfogalmazott cél: a lehető legkisebb NPK-adagokat juttassuk ki úgy, hogy közben a termésbiztonságot, a potenciálisan nagy termésszinteket ne veszélyeztessük (2. táblázat).

Nagyhörcsök. - Mészlepedékes csernozjom talaj. Talajtulajdonságok: fizikai féleség: vályog; $\mathrm{pH}(\mathrm{KCl}): 7,1 ; \mathrm{CaCO}_{3}$-tartalom: 3,9\%; szervesanyag-tartalom: 2,95\%; Nellátottság: közepes. $\mathrm{AL}_{2} \mathrm{P}_{2} \mathrm{O}_{5}: 90 \mathrm{mg} / \mathrm{kg}$ (gyenge P-ellátottság); $\mathrm{AL}-\mathrm{K}_{2} \mathrm{O}: 167 \mathrm{mg} / \mathrm{kg}$ (jó K-ellátottság). Elővetemény: 2,0 t/ha öszi búza, a szalma lekerült a területről. Tervezett termésszint: 6.0 t/ha öszi búza.

A kísérlet klasszikus hiánykísérlet részében 2,3 t/ha N-hatást, 1,0 t/ha P-hatást és 0,4 t/ha K-hatást kaptunk. Az NPK-hatások szintén jól igazolták az új rendszer által megadott NPK-ellátottságok helyes voltát (2. táblázat).

Az előző két kísérlethez hasonlóan, az MTA TAKI-MTA MGKI-2 (környezetkímélö szint) a MÉM NAK intenzív ajánlás 55\%-ának megfelelő összes NPK ( $\mathrm{kg} / \mathrm{ha}$ ) kijuttatásával azzal azonos termésátlagot produkált. Ugyanakkor a csapadékos évjáratban mindhárom kísérleti helyen a minimum ajánlási szint által javasolt $\mathrm{N}$-adag kevésnek bizonyult (2. táblázat). [Itt jegyezzük meg, hogy a gazdálkodóknak legtöbbször a környezetkímélő szint alkalmazását ajánljuk.]

A három kisérleti hely együttes értékelése. - A három IMHOS őszi búza kísérlet átlagában az egyes szaktanácsadási szinteken az őszi búza termések az alábbiak szerint alakultak: MTA TAKI-MTA MGKI-1 (minimum) szint: 6,51 t/ha; MTA TAKI-MTA MGKI-2 (környezetkímélő) szint: 7,34 t/ha; MTA TAKI-MTA MGKI-3 (mérlegszemlélétü) szint: 7,51 t/ha; MTA TAKI-MTA MGKI-4 (maximum) szint: 7,48 t/ha; Talajerőgazdálkodás Kkt (integrált) szint: 7,71 t/ha; MÉM NAK (intenzív) szint: 7,34 t/ha (1. ábra). A legnagyobb termést tehát a Talajerőgazdálkodás Kkt (integrált) szintjén, ill. az MTA TAKI-MTA MGKI-3 (mérlegszemléletű) szintjén kaptuk. Az egyes szaktanácsadási szinteken elért hektáronkénti nettó jövedelmek az alábbiak szerint alakultak: MTA TAKI-MTA MGKI-1 szint: 12 ezer Ft; MTA TAKI-MTA MGKI2: 24 ezer Ft; MTA TAKI-MTA MGKI-3: 24 ezer Ft; MTA TAKI-MTA MGKI-4 szint: 20 ezer Ft; Talajerőgazdálkodás Kkt (integrált) szint: 17 ezer Ft; MÉM NAK (intenzív) szint: 4 ezer Ft (1. ábra). A kalkuláció során a 35 ezer Ft/ha területalapú támogatást nem vettük számításba. Az őszi búza szemterméssel 20 ezer Ft/t áron számoltunk. A gazdaságossági számításokat Sulyok Dénes (Debreceni Egyetem) végezte.

A kísérletek átlagában tehát a legnagyobb nettó jövedelmet az MTA TAKI-MTA MGKI-2, az MTA TAKI-MTA MGKI-3 és az MTA TAKI-MTA MGKI-4 (környezetkíméló, mérlegszemléletü és maximum) szintek eredményezték. Ily módon teljesült az új szaktanácsadási rendszer filozófiájának egyik legfontosabb eleme: a területegységre jutó maximális jövedelem elérése.

Az őszi búza eredmények igazolják az MTA TAKI-MTA MGKI költség- és környezetkímélő trágyázási szaktanácsadási rendszer alapelveinek, mütrágyaadag számítási módszerének helyességét. Mivel az új, költség- és környezetkímélő trágyázási rendszer a hazai szabadföldi trágyázási kísérletek adatbázisán kapott összefüggéseken alapul, ajánlása a lehető legkisebb adagok kijuttatásával mégis a biztonságos termelést, nagy termésszintek elérését teszik lehetővé. 


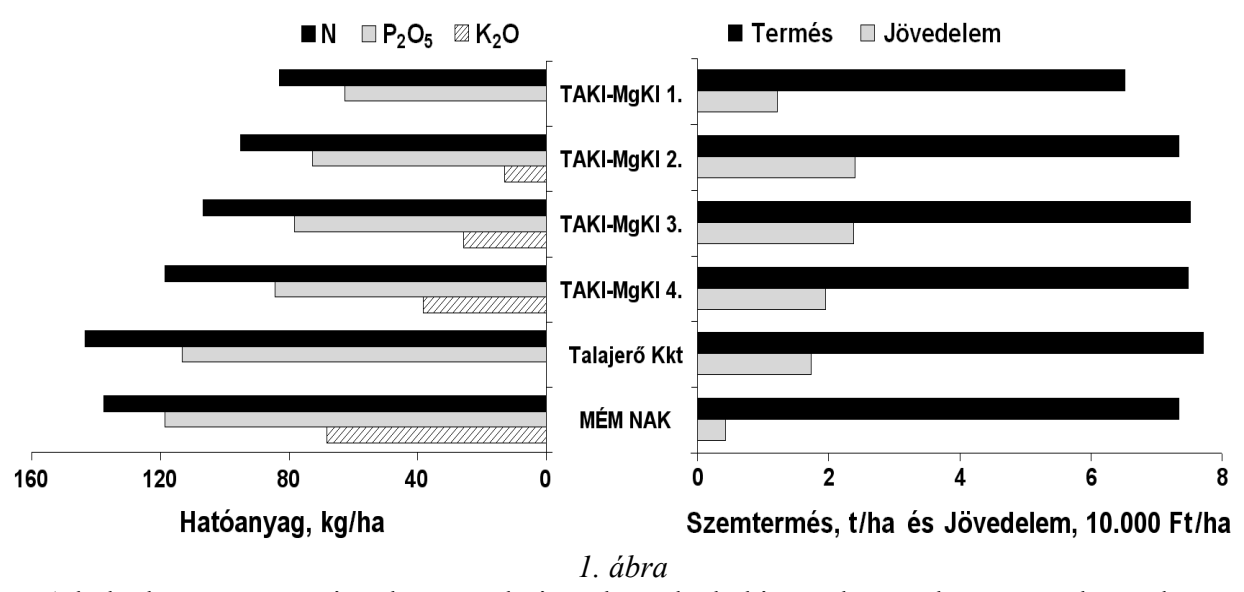

A különböző trágyázási szaktanácsadási rendszerek által javasolt NPK hatóanyagok, az elért termés-, illetve a jövedelemszintek alakulása a 2004. évi IMPHOS őszi búza kísérletekben a három kísérleti hely átlagában

\section{Az IMPHOS kukoricakisérletek, 2005}

2005-ben a kukorica fejlődésének szintén nagyon kedvezett az időjárás. A tél és a tavasz átlagos csapadékmennyiségeket hozott, a nyár viszont meleg és rendkívül csapadékos volt. Júliusban és augusztusban a sokévi átlag 2-3-szorosa is hullott. A kukoricára rendkívül kedvező időjárás 10 t/ha feletti szemtermésmennyiségek elérését tette lehetővé mindhárom helyen. A talajtulajdonságok és a talaj N-ellátottságok mindhárom kísérleti helyen megegyeznek az őszi búza kísérletnél leírtakkal. Mivel az őszi búza - ID. VÁRALlyAY (1950) értékelésével megegyezően - a P-igényes, de kevésbé Kigényes csoportba, a kukorica viszont a kevésbé P-igényes, de K-igényes csoportba tartozik, ugyanazon talaj PK-tartalmak a két növény eltérő PK-ellátottságát jelentik (CSATHÓ, 1997, 2003d,e). Ennek megfelelően, a kevésbé P-igényes kukorica Pellátottságai az őszi búzáénál eggyel jobb, a kukorica K-igényes volta miatt viszont Kellátottságai az őszi búzáéhoz képest eggyel rosszabb kategóriába kerültek.

Balatonszentgyörgy. - N-ellátottság: gyenge, P-ellátottság: jó, K-ellátottság: közepes. Elővetemény: 3,8-7,3 t/ha őszi búza, a szalma alászántásra került. Tervezett termésszint: 8,0 t/ha kukorica (Colomba SC hibrid).

A kísérletben 2,9 t/ha N-hatást, 0,6 t/ha P-hatást és 0,5 t/ha K-hatást mértünk. Az NPK-hatások jól követték az általunk megadott NPK-ellátottságokat. Ez alól talán részben a P-ellátottság volt a kivétel (3. táblázat).

Mindenképpen figyelemre méltó, hogy az MTA TAKI-MTA MGKI-3 (mérlegszemléletü szint) a MÉM NAK intenzív ajánlás 52\%-ának megfelelő összes NPK kijuttatásával a MÉM NAK rendszerével azonos termésátlagot eredményezett (3. táblázat).

Mezőkövesd. - N-ellátottság: jó; P-ellátottság: közepes; K-ellátottság: jó. Elővetemény: 8,8-11,6 t/ha őszi búza, a szalma alászántásra került. A terület 2003 őszén 2 t/ha meszet kapott. Tervezett termésszint: 7,0 t/ha kukorica (Norma SC hibrid). 


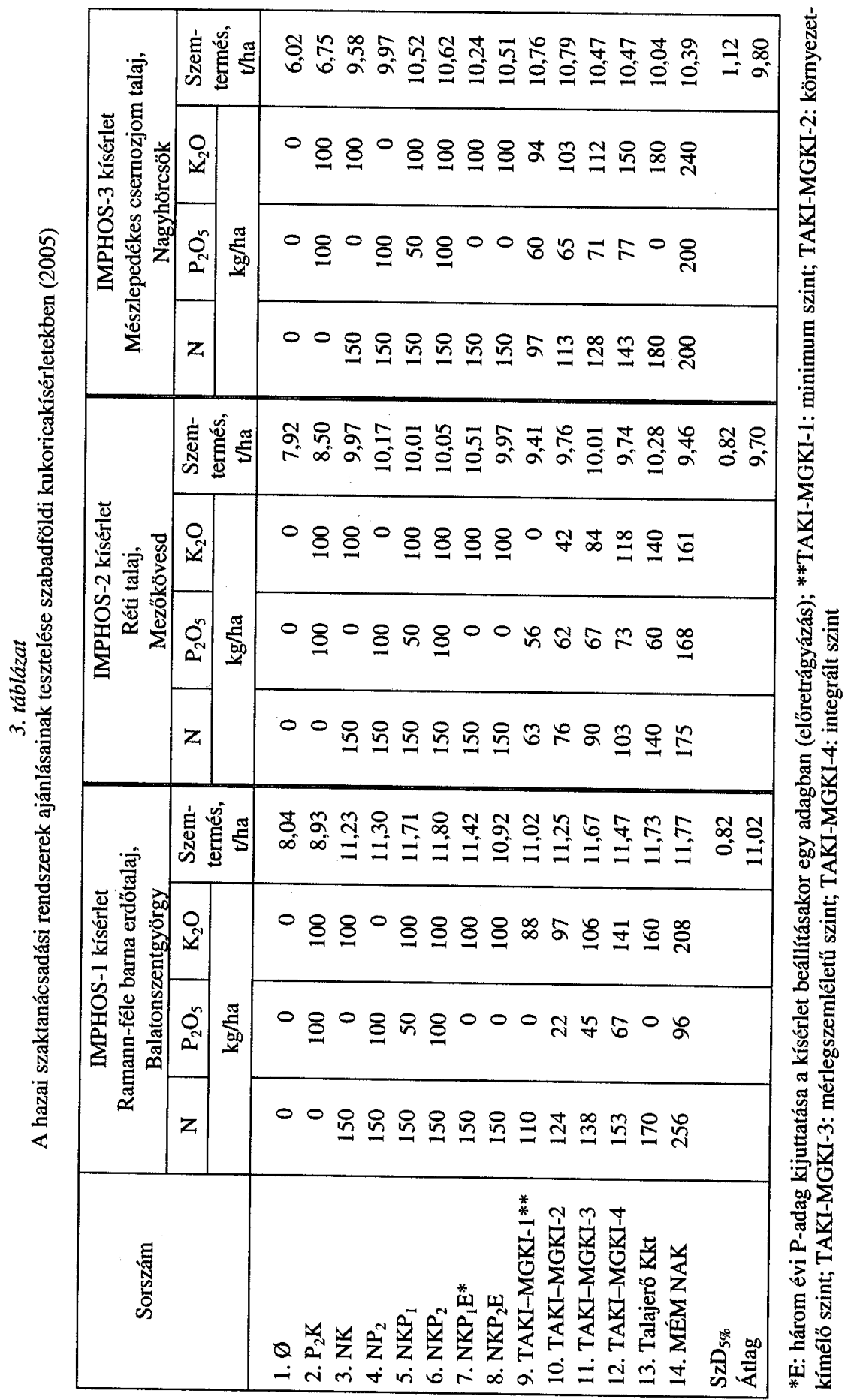


A kísérlet klasszikus hiánykísérlet részében 1,6 t/ha N-hatást, $0,1 \mathrm{t} /$ ha P-hatást és 0,0 t/ha K-hatást kaptunk. Az NPK-hatások többé-kevésbé igazolták a megadott NPKellátottság helyes voltát. Ámbár a P-ellátottság közepes volt, mégsem kaptunk P-hatást a kukoricában. Ennek oka talán az is lehetett, hogy a 2003. őszi meszezés javíthatta a Pfeltáródási folyamatokat (3. táblázat).

A mezőkövesdi kísérletben az MTA TAKI-MTA MGKI-1 (minimum szint) a MÉM NAK intenzív ajánlás 23\%-ának (!) megfelelő összes NPK (kg/ha) kijuttatása mellett a MÉM NAK intenzív ajánlása mellett kapottal azonos termésátlagot produkált (3. táblázat).

Nagyhörcsök. - N-ellátottság: közepes; P-ellátottság: közepes; K-ellátottság: közepes. Elővetemény: 2,6-5,5 t/ha öszi búza, a szalma lekerült a területröl. Tervezett termésszint: 10,0 t/ha kukorica (Norma SC hibrid).

A kísérlet klasszikus hiánykísérlet részében 3,9 t/ha (!) N-hatást, 1,0 t/ha P-hatást és 0,6 t/ha K-hatást kaptunk. Az NPK-hatások szintén jól igazolták a megadott NPKellátottság helyes voltát (3. táblázat).

Az előző kísérlethez hasonlóan, az MTA TAKI-MTA MGKI-1 (minimum szint) a MÉM NAK intenzív ajánlás 39\%-ának megfelelő összes NPK (kg/ha) kijuttatásával a MÉM NAK intenzív ajánlásával kapottal azonos termést eredményezett.

A három kísérleti hely együttes értékelése. - A három IMHOS kukoricakísérlet átlagában az egyes szaktanácsadási szinteken a kukoricatermések az alábbiak szerint alakultak: MTA TAKI-MTA MGKI-1 (minimum) szint: 10,40 t/ha; MTA TAKI-MTA MGKI-2 (környezetkímélö) szint: 10,60 t/ha; MTA TAKI-MTA MGKI-3 (mérlegszemlélétü) szint: 10,72 t/ha; MTA TAKI-MTA MGKI-4 (maximum) szint: 10,56 t/ha; Talajerőgazdálkodás kkt (integrált) szint: 10,68 t/ha; MÉM NAK (intenzív) szint: 10,54 t/ha (2. ábra). A hat ajánlási szinten gyakorlatilag azonosak, 10 t/ha felettiek voltak a szemtermésmennyiségek ebben a kukoricára igen kedvező évben. Ha mégis különbséget teszünk, akkor a legnagyobb termést az MTA TAKI-MTA MGKI-3 (mérlegszemléletü), ill. a Talajerőgazdálkodás Kkt (integrált) szintjén kaptuk. Az egyes szaktanácsadási szinteken elért hektáronkénti jövedelmek Sulyok Dénes (Debreceni Egyetem) számításai szerint az alábbiak szerint alakultak: TAKI-MGKI-1 szint: 78 ezer Ft; TAKI-MGKI-2: 77 ezer Ft; TAKI-MGKI-3: 73 ezer Ft; TAKI-MGKI-4 szint: 62 ezer Ft; Talajerőgazdálkodás Kkt (integrált) szint: 71 ezer Ft; MÉM NAK (intenzív) szint: 25 ezer Ft (2. ábra). A kalkuláció során a 40 ezer Ft/ha területalapú támogatást nem vettük számításba. A kukorica szemterméssel 20 ezer Ft/t áron számoltunk.

A három IMPHOS kukoricakísérlet átlagában tehát a legnagyobb nettó jövedelmet az MTA TAKI-MTA MGKI-1, az MTA TAKI-MTA MGKI-2 és az MTA TAKIMTA MGKI-3 (minimum, környezetkímélő és mérlegszemlélétü) szinteken értünk el. Ily módon a második évben, másik meghatározó gabonanövényünknél is teljesült a költség- és környezetkímélő szaktanácsadási rendszer filozófiájának egyik legfontosabb eleme: a területegységre jutó maximális jövedelem elérése.

A második évi kukorica eredmények is igazolni látszanak az MTA TAKI-MTA MGI költség- és környezetkímélő trágyázási szaktanácsadási rendszer alapelveinek, mütrágyaadag számítási módszerének helyességét. 


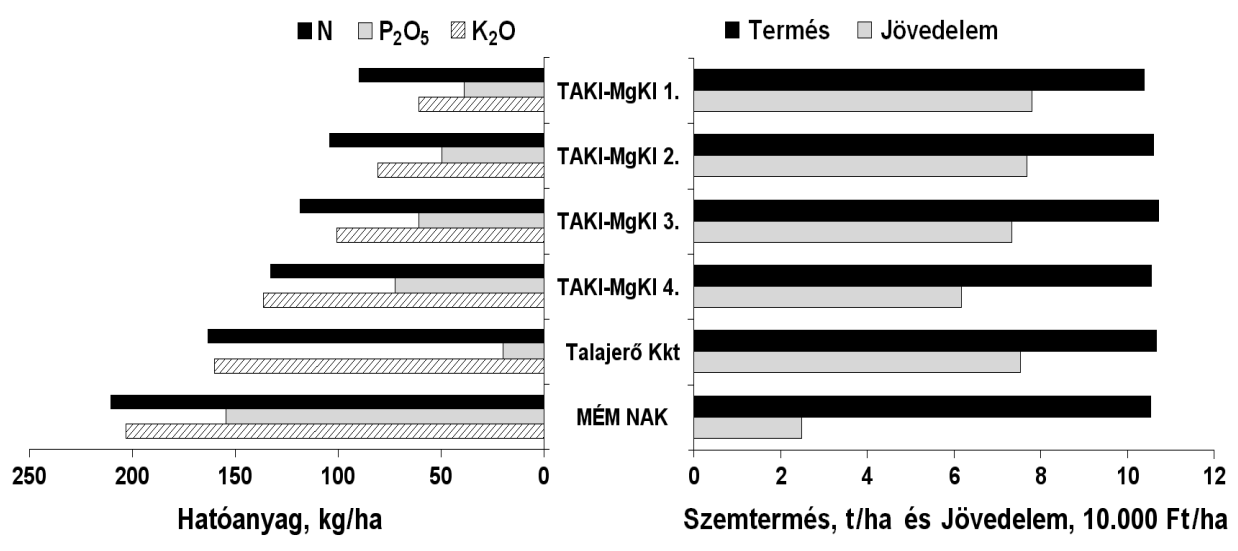

2. ábra

A különböző trágyázási szaktanácsadási rendszerek által javasolt NPK-hatóanyagok, az elért termés-, illetve a jövedelemszintek alakulása a 2005. évi IMPHOS kukoricakísérletekben a három kísérleti hely átlagában

\section{Az IMPHOS tavaszi árpa kísérletek, 2006}

Az időjárás a harmadik évben is kegyes volt az IMPHOS kísérletekhez: tavaszi árpában is viszonylag nagy termések elérését tette lehetővé. Mezökövesden ugyanakkor az agyagos vályog fizikai féleségü réti talajon a tavaszi csapadékos időjárás már belvízfoltok kialakulásához is vezetett. A 2006-ban a tavaszi árpa alá javasolt mütrágyaadagokról, a kapott szemtermésmennyiségekről a 4. táblázat tájékoztat. Itt jelezzük, hogy a balatonszentgyörgyi és a mezőkövesdi kísérletek kiértékelése $1-1 \mathrm{~m}^{2}$-es területekről vett mintakévék alapján történt, míg Nagyhörcsökön 31,5 m²-es nettó területekröl parcellakombájnos betakarítás volt. A betakarított terület nagyságában meglevő nagyságrendnyi különbségek a szignifikáns differencia $\left(\mathrm{SzD}_{5 \%}\right)$ értékek nagyságában is nyomon követhetök voltak.

A talajtulajdonságok és a talaj NPK-ellátottságok mindhárom kísérleti helyen az őszi búza kísérletnél leírtakkal egyeznek meg.

Balatonszentgyörgy. - N-ellátottság: gyenge; P-ellátottság: közepes; K-ellátottság: jó. Elővetemény: 11,0 t/ha kukorica, a szárat alászántották. Tervezett termésszint: 4,8 t/ha tavaszi árpa (Cellar fajta).

A balatonszentgyörgyi tavaszi árpa kísérletben 3,2 t/ha N-hatást, 1,0 t/ha P-hatást és 0,2 t/ha K-hatást regisztráltunk. Az NPK-hatások jól követték az általunk megadott NPK-ellátottságokat. Meglepő, hogy amíg az MTA TAKI-MTA MGKI négy ajánlási szintjéből egyik sem javasolt a mérsékelten K-igényesnek tartott tavaszi árpa alá Ktrágyázást, addig mind a Talajerőgazdálkodás kkt, mind a MÉM NAK intenzív rendszer 100-100 kg/ha körüli K-adagok kijuttatását ajánlotta (4. táblázat).

Ebben a tavaszi árpának kedvező évben a gyenge N-ellátottságú, homokos vályog fizikai féleségű barna erdőtalajon a legnagyobb terméseket a legnagyobb $\mathrm{N}$-adagokat javasló MÉM NAK ajánlásra kaptuk. Ezt a kezelést legjobban (0,6 t/ha-ra) az MTA TAKI-MTA MGKI-3 (mérlegszemléletü) szint közelítette meg. Igaz, hogy míg a MÉM 


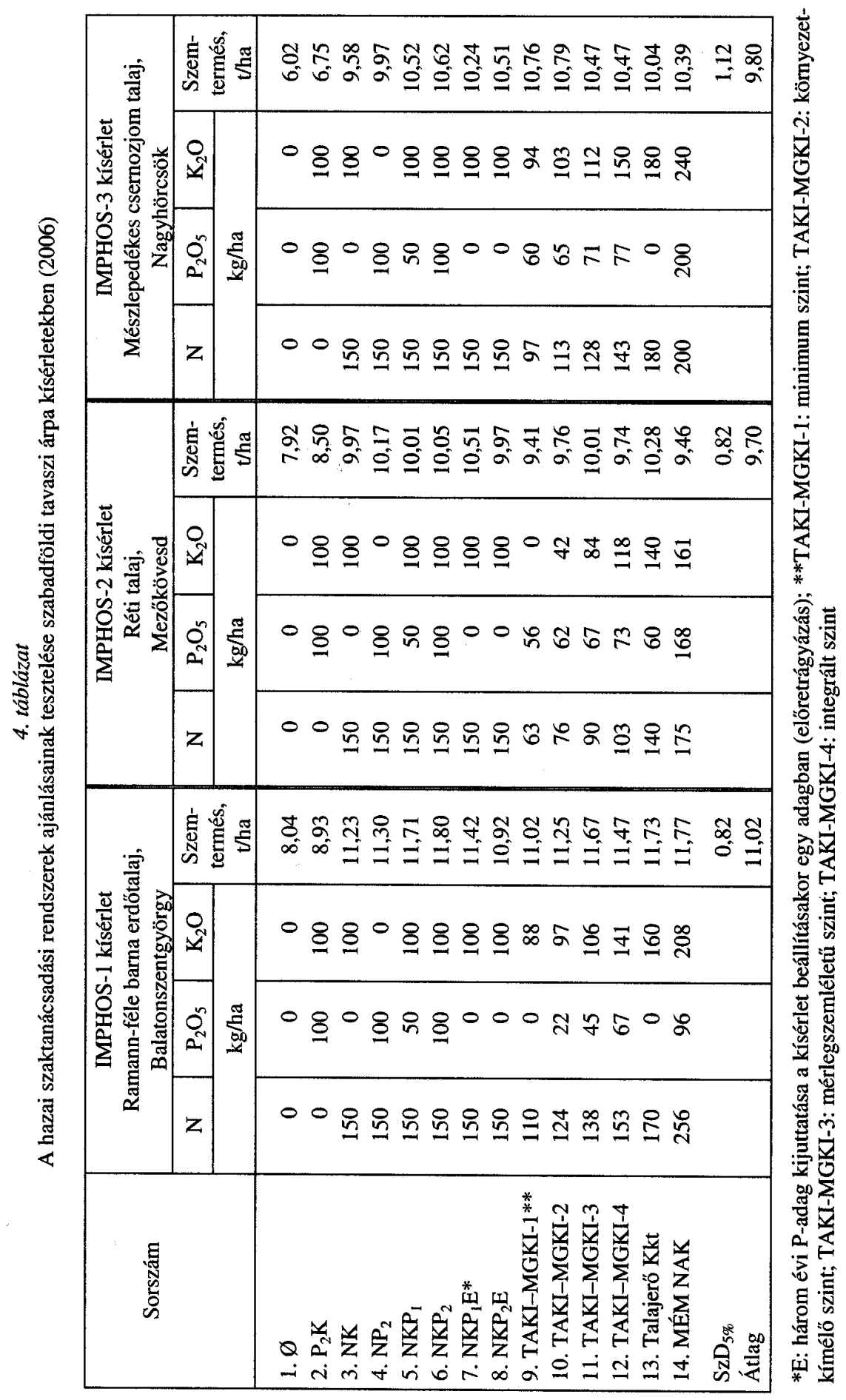


NAK intenzív ajánlásban $281 \mathrm{~kg} /$ ha volt a javasolt $\mathrm{N}-\mathrm{P}_{2} \mathrm{O}_{5}-\mathrm{K}_{2} \mathrm{O}$ mennyiség, addig az MTA TAKI-MTA MGKI-3 (mérlegszemléletü) szintjében csupán $143 \mathrm{~kg} / \mathrm{ha}$, az előbbi $51 \%$-a! Úgy érezzük, ebben a kísérletben is teljesült a rendszer megalkotásakor megfogalmazott cél (4. táblázat).

Mezőkövesd. - N-ellátottság: jó; P-ellátottság: gyenge; K-ellátottság: igen jó. Elővetemény: 9,7 t/ha kukorica, a szárat alászántották. Tervezett termésszint: 5,0 t/ha tavaszi árpa (Jubilant fajta).

A kísérlet klasszikus hiánykísérlet részében 2,7 t/ha N-hatást, 0,8 t/ha P-hatást és 0,0 t/ha K-hatást kaptunk. Az NPK-hatások megbízhatóan visszaigazolták az általunk megadott NPK-ellátottságok helyes voltát. A 2005/2006. év tavaszi csapadékos időjárása ugyanakkor belvízfoltok kialakulásához is vezetett, lehetetlenné téve a kísérlet parcellakombájnos betakarítását (4. táblázat).

A mezőkövesdi kísérletben a hat szaktanácsi ajánlásban az NP-adagokban kisebb, míg a K-adagokban számottevő különbségek voltak. A balatonszentgyörgyi kísérlethez hasonlóan az MTA TAKI-MTA MGKI négy ajánlási szintjéből egyik sem javasolt a mérsékelten K-igényesnek tartott tavaszi árpa alá K-trágyázást ezen a jó K-ellátottságú területen, míg mind a Talajerőgazdálkodás kkt, mind a MÉM NAK intenzív rendszer 100-100 kg/ha körüli K-adagokat javasolt (4. táblázat). A mezökövesdi kísérletben a legnagyobb termések az MTA TAKI-MTA MGKI-3 (mérlegszemléletü) és a Talajerőgazdálkodás kkt ajánlásaihoz kötődtek. Az MTA TAKI-MTA MGKI-3 (mérlegszemléletü) ajánlásban azon túl, hogy a legnagyobb volt a termés, a MÉM NAK intenzív rendszer $263 \mathrm{~kg} /$ ha összes $\mathrm{N}_{2} \mathrm{P}_{2} \mathrm{O}_{5}-\mathrm{K}_{2} \mathrm{O}$ mennyiségéhez képest csupán $144 \mathrm{~kg} / \mathrm{ha}$ (annak 55\%-a) volt a javasolt NPK-adag. Az MTA TAKI-MTA MGKI-3 kezelés közel feleannyi NPK felhasználásával újra csak ugyanakkora termést biztosított, mint a MÉM NAK intenzív ajánlása (4. táblázat).

Nagyhörcsök. - N-ellátottság: közepes; P-ellátottság: gyenge; K-ellátottság: jó. Elövetemény: 9,8 t/ha kukorica, a szár lekerült a területről. Tervezett termésszint: 5,5 t/ha tavaszi árpa (Jubilant fajta).

A kísérlet klasszikus hiánykísérlet részében 2,7 t/ha N-hatást, 1,6 t/ha P-hatást (!) és 0,3 t/ha K-hatást kaptunk. A három kísérletből itt volt a leggyengébb a P-ellátottság és a legnagyobb a P-hatás. Az NPK-hatások szintén jól igazolták az általunk megadott NPKellátottság helyes voltát (4. táblázat).

A három kísérleti hely közül itt volt a legnagyobb a MÉM NAK intenzív rendszer által javasolt $\mathrm{N}-\mathrm{P}_{2} \mathrm{O}_{5}-\mathrm{K}_{2} \mathrm{O}$ mennyisége: $346 \mathrm{~kg} / \mathrm{ha}$. A hat trágyázási ajánlási szintből öt csaknem azonos termést adott. Az MTA TAKI-MTA MGKI-2 (környezetkímélö) szinten $150 \mathrm{~kg}$ /ha NPK felhasználásával - amely a MÉM-NAK ajánlás csupán 43\%-a (!) azzal azonos termést kaptunk. Úgy tünik ugyanakkor, hogy a 2006. évi csapadékos évjáratban az MTA TAKI-MTA MGKI-1 minimum szinten javasolt N-adag mindhárom kísérleti helyen kevésnek bizonyult. Ennek alapján a közelmúltban módosítottuk a szaktanácsadási rendszer ide vonatkozó sarokszámait, növeltük a tavaszi árpa alá javasolt $\mathrm{N}$-adagokat. A gazdálkodóknak mindemellett a környezetkímélő szint ajánlását javasoljuk inkább (4. táblázat).

A három kisérleti hely együttes értékelése. - 2006-ban a 3 IMPHOS tavaszi árpa kísérlet átlagában a kijuttatott NPK-adagok vonatkozásában számottevő különbségeket tapasztaltunk. Különösen igaz ez a káliumra, és részben a foszforra. A legnagyobb termést a MÉM NAK szerinti kezelésben (4,84 t/ha) és az MTA TAKI-MTA MGKI-3 
(mérlegszemléletü) kezelésben (4,78 t/ha) kaptuk. A legkisebb termések az MTA TAKI-MTA MGKI-1 (minimum) (4,15 t/ha) és az MTA TAKI-MTA MGKI-2 (környezetkímélő) (4,34 t/ha) ajánlási szintekhez voltak köthetők (3. ábra).

A gazdaságossági számítások szerint viszont a legkedvezőbb ajánlásoknak az MTA TAKI-MTA MGKI-3 (mérlegszemléletü) (34 ezer Ft/ha jövedelem), valamint az MTA TAKI-MTA MGKI-1 (minimum) és az MTA TAKI-MTA MGKI-2 (környezetkímélő)

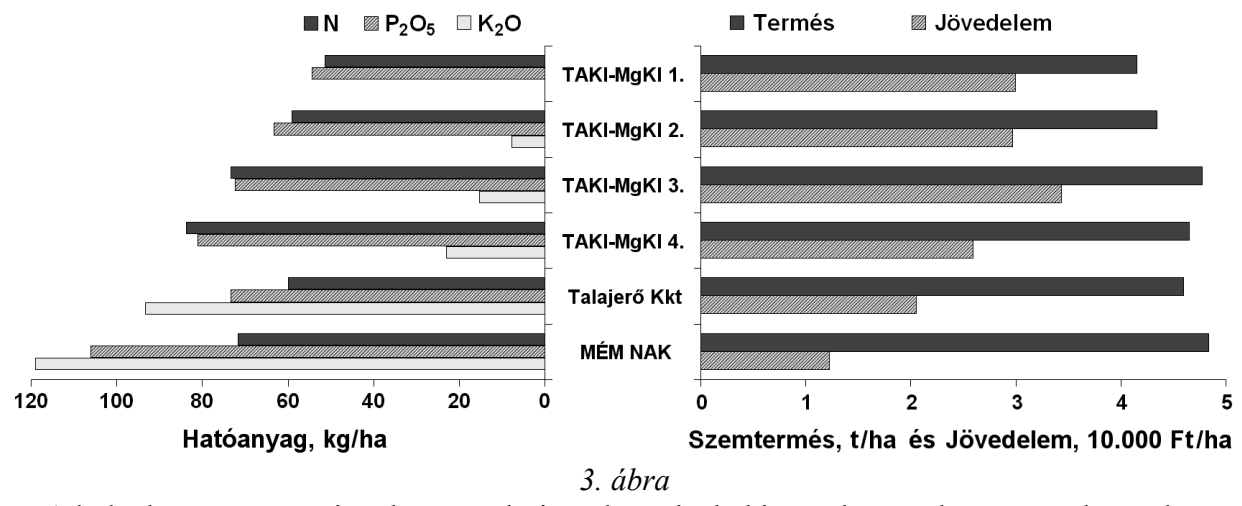

A különböző trágyázási szaktanácsadási rendszerek által javasolt NPK-hatóanyagok, az elért termés-, illetve a jövedelemszintek alakulása a 2006. évi IMPHOS tavaszi árpa kísérletekben a három kísérleti hely átlagában

szintek (30-30 ezer Ft/ha tiszta jövedelem) bizonyultak. Az MTA TAKI-MTA MGKI4 (maximum) szinthez 26 ezer Ft/ha, a Talajerőgazdálkodás kkt ajánláshoz 21 ezer Ft/ha, míg a MÉM NAK intenzív rendszer ajánlásához 12 ezer Ft/ha tiszta jövedelem volt köthető a tavaszi árpával 2006-ban a 3 kísérleti hely átlagában. A tiszta jövedelembe nem számoltuk bele a területalapú támogatásokat.

A harmadik évi tavaszi árpa eredmények is igazolták az MTA TAKI-MTA MGKI költség- és környezetkímélő szaktanácsadási rendszer alapelveinek, mütrágyaadag számítási módszerének helyességét. Mivel az a hazai szabadföldi trágyázási kísérletek adatbázisán kapott összefüggéseken alapul, az ajánlások a lehető legkisebb adagok kijuttatásával biztonságos termelést, nagy termések elérését, a területegységre jutó maximális jövedelmek elérését teszik lehetővé.

\section{Összefoglalás}

Az 1960 és 2000 között publikált hazai trágyázási tartamkísérletek adatbázisán kapott összefüggésekre alapozva új költség- és környezetkímélő trágyázási rendszert hoztunk létre. A számítógépes szaktanácsadási rendszer a növénytermesztő szakemberek rendelkezésére álló tápanyagforrások ésszerü és gazdaságos felhasználásához kíván segítséget nyújtani. Figyelembe véve az utóbbi 10-15 év hazai tápanyag-gazdálkodásának kihívásait, a mütrágyaár-támogatások megszüntetését, a megszigorodott gazdasági környezetet - a korábbi szaktanácsadási módszerek értékeit megőrizve dolgoztunk ki a 48 legfontosabb szántóföldi növény makro- és mikroelem-trágyázási rendszerét. A 
korábbi intenzív (MÉM NAK, 1979, „kék füzet”) rendszer történelmi küldetést töltött be, amikor a talajok PK-ellátottságának gyors javítását és az élelmiszerellátás biztonságát, mint fontos stratégiai cél elérését biztosította. Mezőgazdaságunk, igaz, rohamosan csökkenő mértékben, de részben ma is az akkor felhalmozott PK-tápelem tőkét hasznosítja.

Az új szaktanácsadási rendszer megalkotása során a korábbi szaktanácsadási rendszerek értékeit igyekeztünk beépíteni az új rendszerbe. Az MTA TAKI-MTA MGKI szaktanácsadási rendszer egyik nagy erőssége, hogy a jelenleg legszélesebb hazai szabadföldi kísérleti háttéren alapul: a rendszerbe beépítettük az 1960 és 2000 között publikált, a hazai növénytáplálási iskolák (egyetemek, kutatóintézetek, OMTK) által beállított szabadföldi trágyázási kísérletek eredményeinek adatbázisán kapott összefüggéseket. Célunk volt, hogy az új rendszer ajánlásai a lehető legkisebb adagok kijuttatásával biztonságos termelést, nagy termések elérését, a területegységre jutó maximális jövedelmek elérését tegyék lehetővé. A környezet- és költségkímélő trágyázási szaktanácsadási rendszer négy mütrágyázási szinten ad szaktanácsot: 1. minimum; 2. környezetkímélö; 3. mérlegszemléletü és 4. maximum növénytáplálási szint.

A Nemzetközi Foszfor Intézet (IMPHOS) finanszírozásában egy hároméves program keretében jellegzetes hazai talajokon (barna erdőtalaj, csernozjom, réti talaj), őszi búza, kukorica és tavaszi árpa növényekkel teszteltük a magyarországi trágyázási szaktanácsadási rendszereket (MTA TAKI-MTA MGKI költség- és környezetkímélö rendszer négy szintjét; Talajerőgazdálkodás kkt integrált rendszer; MÉM NAK intenzív rendszer). A kísérletek első 6 kezelésének klasszikus hiánykísérlet-felépítése lehetővé tette a talaj NPK-ellátottsági kategóriák tesztelését is.

Az IMPHOS tesztkísérletek mindhárom talajon, valamennyi növénynél igazolták az MTA TAKI-MTA MGKI költség- és környezetkímélő szaktanácsadási rendszer alapelveinek, mütrágyaadag számítási módszerének helyes voltát: a MÉM NAK intenzív összes NPK-adag ajánlásainak esetenként 40-60\%-ának kijuttatásával az új MTA TAKI-MTA MGKI rendszer a MÉM NAK intenzív ajánlásával kapottal azonos, nagy terméseket eredményezett. Mindezek eredményeképpen, a területegységre jutó legnagyobb jövedelmeket is az új költség- és környezetkímélő rendszer ajánlásaival kaptuk.

\section{Irodalom}

ÁngYÁN J. \& MENYHÉRT Z., 1997. Alkalmazkodó növénytermesztés, ésszerű környezetgazdálkodás. Mezőgazdasági Szaktudás Kiadó. Budapest.

ÁNGYÁN J. \& MENYHÉRT Z. (szerk.), 2004. Alkalmazkodó növénytermesztés, környezet- és tájgazdálkodás. (2. átdolg., bővített kiadás). Mezőgazdasági Szaktudás Kiadó. Budapest.

ÁrendÁs T. \& CSATHÓ P., 1994. Azonos NPK-hatóanyagú szerves- és mütrágyázás hatása a talajtulajdonságok függvényében. Agrokémia és Talajtan. 43. 399-407.

ÁRENDÁs, T. \& CSATHÓ, P., 2002. Comparison of the effect of equivalent nutrients given in the form of farmyard manure or fertilizers in Hungarian long-term field trials. Commun. Soil Sci. Plant Anal. 33. 2861-2878.

BALLA A.-NÉ, 1991a. A trágyázási szaktanács fejlődése és módszerei. I. Növénytermelés. 40. 363-373.

BALlA A.-NÉ, 1991b. A trágyázási szaktanács fejlődése és módszerei. II. A magyar trágyázási szaktanács fejlödése. Növénytermelés. 40. 553-560. 
BALLA A.-NÉ, 1992a. A trágyázási szaktanács módszerei. III. A magyar szaktanácsadás jelenlegi helyzete. Növénytermelés. 41. 83-89.

BALLA A.-NÉ, 1992b. A trágyázási szaktanács módszerei. IV. A foszfor, a kálium és egyéb ásványi elemek trágyázása Nyugat-Európában. Növénytermelés. 41. 463-471.

BALlA A.-NÉ, 1993. A trágyázási szaktanács módszerei. V. N-trágyázás Nyugat- és ÉszakEurópában. Növénytermelés. 42. 103-113.

BALLA A.-NÉ, 1994. A trágyázási szaktanács módszerei. VI. Európán kívüli tanácsadási módszerek. Növénytermelés. 43. 175-182.

BERZSENYI Z., 1993. A N-mütrágyázás és az évjárat hatása a kukorica hibridek (Zea mays L.) szemtermésére és a N-mütrágya reakciójára tartamkísérletben az 1970-1991. években. Növénytermelés. 42. 49-62.

BuZÁS I.-NÉ, KARKALIK A.-NÉ \& TiHANYI L., 1988. A műtrágyázási szaktanácsadás és a műtrágyázás gyakorlatának összehasonlítása az 1987. évi kukoricatermesztési adatok alapján. Hungagrochem ' $88.183-189$.

CSATHÓ P., 1997. Összefüggés a talaj K-ellátottsága és a kukorica, őszi búza és lucerna K-hatások között a hazai szabadföldi kísérletekben, 1960-1990. Agrokémia és Talajtan. 46. 327-345.

CsATHÓ P., 2001a. Összefüggés a talajsavanyodás mértéke és a mészhatások között a hazai szabadföldi kísérletek adatbázisán, 1950-1998. I. A mészformák és a talajtulajdonságok szerepe a mészhatások megjelenésében. Agrokémia és Talajtan. 50. 103-118.

CSATHÓ P., 2001b. Összefüggés a talajsavanyúság mértéke és a mészhatások között a hazai meszezési tartamkísérletek adatbázisán, 1950-2000. II. A kísérleti növények, a mészforma és a meszezés óta eltelt idő szerepe a mészhatások megjelenésében. Agrokémia és Talajtan. 50. 509-523.

CsathÓ P., 2002. Az AL-P korrekciós modell értékelése a hazai szabadföldi őszi búza Pkísérletek adatbázisán, 1960-2000. Agrokémia és Talajtan. 51. 351-380.

CsATHÓ P., 2003a. Öszi búza N-hatásokat befolyásoló tényezők vizsgálata az 1960 és 2000 között publikált hazai szabadföldi kísérletek adatbázisán. Növénytermelés. 52. 41-59.

CsATHÓ P., 2003b. Lucerna N-hatásokat befolyásoló tényezők vizsgálata az 1960 és 2000 között publikált hazai szabadföldi kísérletek adatbázisán. Növénytermelés. 52. 243-253.

CSATHÓ P., 2003c. Kukorica N-hatásokat befolyásoló tényezők vizsgálata az 1960 és 2000 között publikált hazai szabadföldi kísérletek adatbázisán. Agrokémia és Talajtan. 52. 169-184.

CSATHÓ P., 2003d. Kukorica P-hatásokat befolyásoló tényezők vizsgálata az 1960 és 2000 között publikált hazai szabadföldi kísérletek adatbázisán. Agrokémia és Talajtan. 52. 455-472.

CSATHÓ P., 2003e. Öszi búza P-hatásokat befolyásoló tényezők vizsgálata az 1960 és 2000 között publikált hazai szabadföldi kísérletek adatbázisán. Növénytermelés. 52. 679-701.

CsATHÓ P., 2004. Lucerna P-hatásokat befolyásoló tényezők vizsgálata az 1960 és 2000 között publikált hazai szabadföldi kísérletek adatbázisán. Növénytermelés. 53. 141-156.

CsATHÓ P., 2005a. Öszi búza K-hatásokat befolyásoló tényezők vizsgálata az 1960 és 2000 között publikált hazai szabadföldi kísérletek adatbázisán. Növénytermelés. 54. 197-213.

CsATHÓ P., 2005b. Kukorica K-hatásokat befolyásoló tényezők vizsgálata az 1960 és 2000 között publikált hazai szabadföldi kísérletek adatbázisán. Növénytermelés. 54. 447-465.

Csathó, P., ÁrendÁs, T. \& NÉmeth, T., 1998a. New, environmentally friendly fertiliser advisory system, based on the data set of the Hungarian long-term field trials set up between 1960 and 1995. Commun.Soil Sci. Plant Anal. 29. 2161-2174.

Csathó, P., ÁRENDÁs, T. \& NÉMETH, T., 1998b. New, environmentally friendly fertilizer recommendation system for Hungary. In: Codes for Good Agricultural Practice and Balanced Fertilization. Proc. Int. Symp. CIEC, PFS and Workshop IMPHOS, IPI, Pulawy, Poland. (Ed.: Fotyma, M.) Bibliotheca Fragmenta Agronomica. 3. 225-230.

CSATHÓ P., ÁrendÁs T. \& NÉMETH T., 2003. Növénytáplálási stratégiák a modern, költség- és környezetkímélő földhasználat szolgálatában. In: Földminősítés és földhasználati információ a mezőgazdaság versenyképességének javításáért. (Szerk.: GAÁL Z., MÁTÉ F. \& TóTH G.) 213-218. Veszprémi Egyetem. Keszthely. 
CSATHÓ P., ÁrendÁs T. \& NÉMETH T., 2005a. Környezetkímélő tápanyag-utánpótlási rendszer gyakorlati tapasztalatai szántóföldi kultúrában. Agronapló. IX. (2) 60-62.

CsATHÓ, P., ÁRENDÁs, T. \& NÉMETH, T., 2005b. Testing various fertilizer recommendations: The Hungarian fertilizer advisory systems. IMPHOS Phosphate Newsletter. No. 23. 8-11.

CSATHÓ P., ÁRENDÁS T. \& NÉMETH T., 2006a. Új, költség- és környezetkímélö trágyázási szaktanácsadási rendszer az agrár-környezetgazdálkodási program eredményes megvalósításáért. Agronapló. X. (2) 27-29.

CSATHÓ P., ÁrendÁs T. \& NÉMETH T., 2006c. (Tápanyag)gazdálkodj okosan! Gyakorlati Agrofórum. Extra 14. 2006/3. 13-15.

CSATHÓ P., KÁDÁR I. \& SARKADI J., 1989. A kukorica mütrágyázása meszes csernozjom talajon. Növénytermelés. 38. 69-76.

CSATHÓ P. et al., 2004a. Intenzív, iparszerü, illetve integrált, környezetkímélő tápanyagellátási, trágyázási szaktanácsadási rendszerek. In: Alkalmazkodó növénytermesztés, környezet- és tájgazdálkodás. (2. átdolg., bővített kiadás) (Szerk.: ÁNGYÁn J. \& MENYHÉRT Z.) 208-218. Mezőgazdasági Szaktudás Kiadó. Budapest.

CSATHÓ P. et al., 2004b. Új költségkímélő szántóföldi zöldség trágyázási szaktanácsadási rendszer. Gyakorlati Agrofórum. 15. (8) 40-43.

CSATHÓ P. et al., 2005c. Szántóföldi zöldségnövényeink új költség- és környezetkímélő trágyázási szaktanácsadási rendszere. Agronapló. IX. (6-7) 68-72.

CsATHÓ P. et al., 2005d. A fenntartható tápanyag-gazdálkodás alapelvei. In: A magyar mezőgazdaság elemforgalma 1901 és 2003 között. Agronómiai és környezetvédelmi tanulságok. (Szerk.: KovÁCs G. J. \& CsATHÓ P.) 235-244. MTA TAKI-FVM. Budapest.

CsATHÓ P. et al., 2006b. A kukorica költség- és környezetkímélő trágyázásának gyakorlati tapasztalatai. Gyakorlati Agrofórum. Extra 13. 2006/2. 29-30.

CSATHÓ P. et al., 2006d. Új trágyázási szaktanács. Magyar Mezőgazdaság. (27) 12-14.

CsATHÓ P. et al., 2006e. Készítsük együtt az AKG tápanyag-gazdálkodási terveket! Őstermelő. X. (5) 39-41.

DeBreCZeni B \& DeBreCZENi B.-NÉ (szerk.), 1994. Trágyázási kutatások 1960-1990. Akadémiai Kiadó. Budapest.

GYAKORLATI AGROFÓRUM. 2006. Útkeresés IX. Tápanyag-gazdálkodás. 12/M. 1-32.

KÁDÁR I., 1988. Kevesebb mütrágyát! Búvár. 7. 13.

KÁDÁR I., 1992. A növénytáplálás alapelvei és módszerei. MTA TAKI-AKAPRINT. Budapest.

KADlicsKó B., KRISZTiÁN J. \& Holló S., 1988. Kálium mütrágyázási kísérletek eredményei barna erdőtalajokon. Növénytermelés. 37. 43-51.

KRISZTiÁN J. \& Holló S., 1992. Periodikus foszfor mütrágyázás. Növénytermelés. 41. 141-148.

LÁsZTiTY B., 1989. A kálium mütrágyázás hatása a termésre karbonátos homoktalajon. Növénytermelés. 38. 559-568.

MÉM NAK, 1979. Műtrágyázási irányelvek és üzemi számítási módszer. MÉM NAK. Budapest.

NAGY J., 1995. A mütrágyázás hatásának értékelése a kukorica (Zea mays L.) termésére eltérő évjáratokban. Növénytermelés. 44. 493-506.

NÉMETH, T., 2006. Application of the Bray-Mitscherlich equation approach for economically and environmentally sound fertilization of field crops in Hungary. Commun. Soil Sci. Plant Anal. 37. 2227-2247.

NÉmeth, T., Csathó, P. \& Árendás, T., 2001. New, environmentally friendly wheat fertilizer advisory system for Hungary. In: Bedő, Z. and Láng, L. (szerk.): Wheat in a Global Environment. Developments in Plant Breeding. (Eds.: BEDÖ Z. \& LÁNG, L.) Vol. 9. 625-631. Kluwer Academic Publishers. Dordrecht-Boston-London.

NÉMETH T., KOVÁCS G. \& KÁDÁR I., 1987-1988. A nitrát, a szulfát és a vízoldható sók bemosódásának vizsgálata mütrágyázási tartamkísérletben. Agrokémia és Talajtan. 36-37. 110-126.

SARKADi J., THAMM F.-NÉ \& PUSZTAi A., 1987. A talaj P-ellátottságának megítélése a korrigált AL-P segítségével. Melioráció-Öntözés és tápanyaggazdálkodás. 66-72. Agroinform. Budapest. 
SzÜCs E., 2006. Az ÉGyDKF környezetkímélő gyümölcsös fenntartó trágyázási szaktanácsadási rendszere jellemzői, felépítése, alapelve. Kézirat. Budapest.

SzÖKE L., 2006. A szőlő környezetkímélö fenntartó trágyázási szaktanácsadási rendszere jellemzői, felépítése, alapelve. Kézirat. Kecskemét.

TERBE I., KAPPEL N. \& CSATHÓ P., 2005. Új irányelvek a szántóföldi zöldségfélék trágyázásában. Gyakorlati Agrofórum. 16. (6) 51-56.

TERBE I. et al., 2004. A szükséges tápanyagmennyiség meghatározása. In: Környezetkímélő tápanyag-gazdálkodás a szabadföldi zöldségtermesztésben. A szántóföldi zöldségnövények új, környezetkímélő tápanyag-gazdálkodási szaktanácsadási rendszere. (Szerk.: TERBE I. \& CSATHÓ P.) 25-41. Budapesti Corvinus Egyetem KTK-MTA TAKI. Budapest.

ID. VÁRALLYAY GY., 1950. A műtrágyázást irányító kísérletek és vizsgálatok. Agrokémia. 2. 287 302.

VÁRAllyay, Gy. et al., 1992. New plant nutrition advisory system in Hungary. Commun. Soil Sci. Plant Anal. 23. 2053-2073.

Érkezett: 2007. február 12.

${ }^{1}$ CSATHÓ PÉTER, ${ }^{2}$ ÁRENDÁS TAMÁS, ${ }^{1}$ FODOR NÁNDOR és ${ }^{1}$ NÉMETH TAMÁS

${ }^{1}$ MTA Talajtani és Agrokémiai Kutatóintézet, Budapest és

${ }^{2}$ MTA Mezőgazdasági Kutatóintézete, Martonvásár

Postai cím: CSATHÓ PÉTER, MTA Talajtani és Agrokémiai Kutatóintézet, 1022 Budapest, Herman Ottó út 15.E-mail: csatho@rissac.hu 